\section{Jelena Pasarić} Marina Đurović

Jelena Pasarić Marina Đurović Hrvatski restauratorski zavod Odjel za štafelajno slikarstvo jpasaric@hrz.hr, mdurovic@hrz.hr

Prethodno priopćenje / Preliminary communication

Primljen / Received: 7. 6. 2021.

UDK: 75.041.5(497.5 Trakošćan)"15" DOI: https://doi.org/10.17018/portal.2021.8

\title{
Alberto Marliani u srcu Bednje
}

SAŽETAK: Objedinjujući rezultate konzervatorsko-restauratorskih, prirodoznanstvenih, povijesnoumjetničkih i povijesnih istraživanja na slici iz dvorca Trakošćan, evidentiranoj pod imenom Neutvrđeni muškarac (možda Maksimilijan I. Habsburški), tekst donosi spoznaje o porijeklu, vremenu nastanka i složenim mijenama slike koja je na jednom platnu nosila tri superponirana portreta triju različitih osoba povezanih $\mathrm{s}$ Milanskim Vojvodstvom i obitelji Sforza u tri različita perioda. Otkriveni izvorni renesansni portret iz ranog 16. stoljeća prikazuje plemića Alberta Marlianija i primjer je leonardesknog smjera lombardskog slikarstva visoke renesanse, ali i izniman primjer ranog portretnog slikarstva sačuvan na tlu kontinentalne Hrvatske.

KLJUČNE RIJEČI: Trakošćan, leonardeski, manirizam, Sforza, Marliani, raslojavanje, Maksimilijan I. Habsburg

$\mathrm{S}$ lika Neutvrđeni muškarac (Maksimilijan I. Habsburški) iz bogate zbirke portreta Muzeja dvorca Trakošćan, dugo je bila pohranjena u depou Dvora Trakošćan. Zbog osipanja slikanog sloja, slika je uvrštena u prioritete za konzerviranje-restauriranje te je $u$ Trakošćanu obavljena njezina preventivna konsolidacija, a tijekom 2018., u Hrvatskom restauratorskom zavodu izvedeni su cjeloviti konzervatorsko-restauratorski radovi. Konzervatorskorestauratorskim i prirodoslovnim istraživanjima utvrđene su tri naknadne intervencije na slici te prisutnost dvaju starijih portreta ispod portreta neutvrđenog muškarca.

Proširena konzervatorsko-restauratorska i prirodoslovna istraživanja, uz povijesnoumjetničku valorizaciju, prethodila su odluci o odstranjivanju svih naknadnih intervencija na slici. Nakon uspješnog raslojavanja povijesnih slojeva i otkrivanja izvornog portreta, neobični je put ove „žrtve recikliranja“ postao inspiracija za proširena arhivska, povijesnoumjetnička i povijesna istraživanja kako bi se osvijetlilo podrijetlo i vrijeme nastanka slike.

\section{Portret neutvrđenog muškarca}

Djelo neutvrđenog autora slikano je uljem na platnu dimenzija 119 x 87,5 cm i bilo je datirano u 15 . stoljeće. ${ }^{1}$ Prikazuje tričetvrt figuru mlađeg muškarca, čije je tijelo $u$ desnom poluprofilu, dok mu je glava u gotovo čistom profilu, također okrenuta udesno. Odjeven je u zagasito 


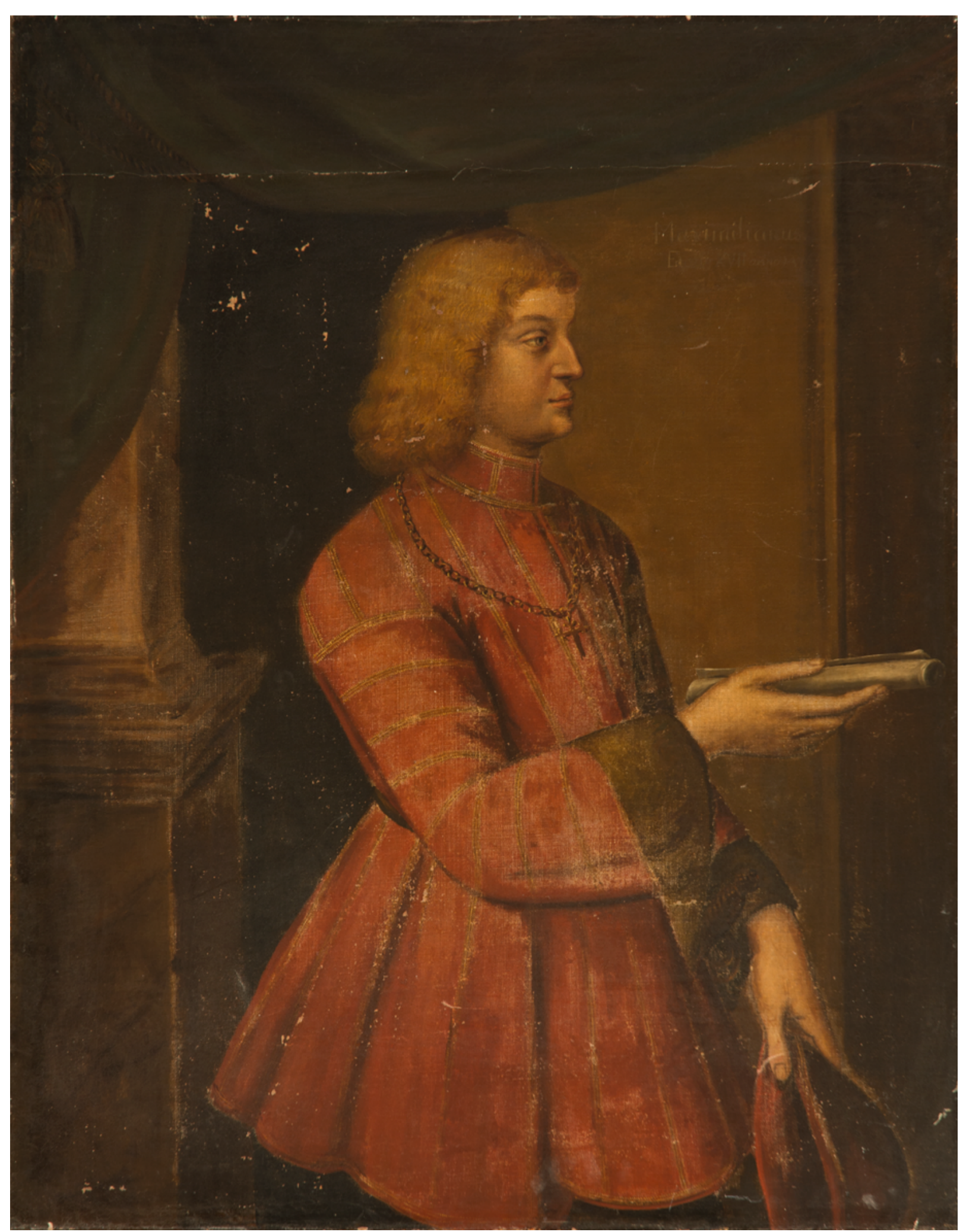

1. Nepoznati slikar, Neuturđeni muškarac (Maksimilijan I. Habsburški), Trakošćan, Dvor Trakošćan, zatečeno stanje (arhiva HRZ-a, snimka: ). Škudar, 2016.)

Unknown artist, Unidentified Man (Emperor Maximilian I), Trakošćan, Castle Trakošćan, condition before conservation (HRZ Photo Archive, J. Škudar, 2016)

crveni haljetak dužine iznad koljena s upadljivim tamnozelenim manžetama. Oko vrata ima lanac s privjeskom u obliku križa, u spuštenoj lijevoj ruci drži kapu, a u desnoj ruci, savijenoj u laktu, drži svitak. Mladić stoji u interijeru definiranom štafažnom arhitekturom. Iza njegovih leđa, duž lijevog ruba slike, nalazi se kvadratni stup s 


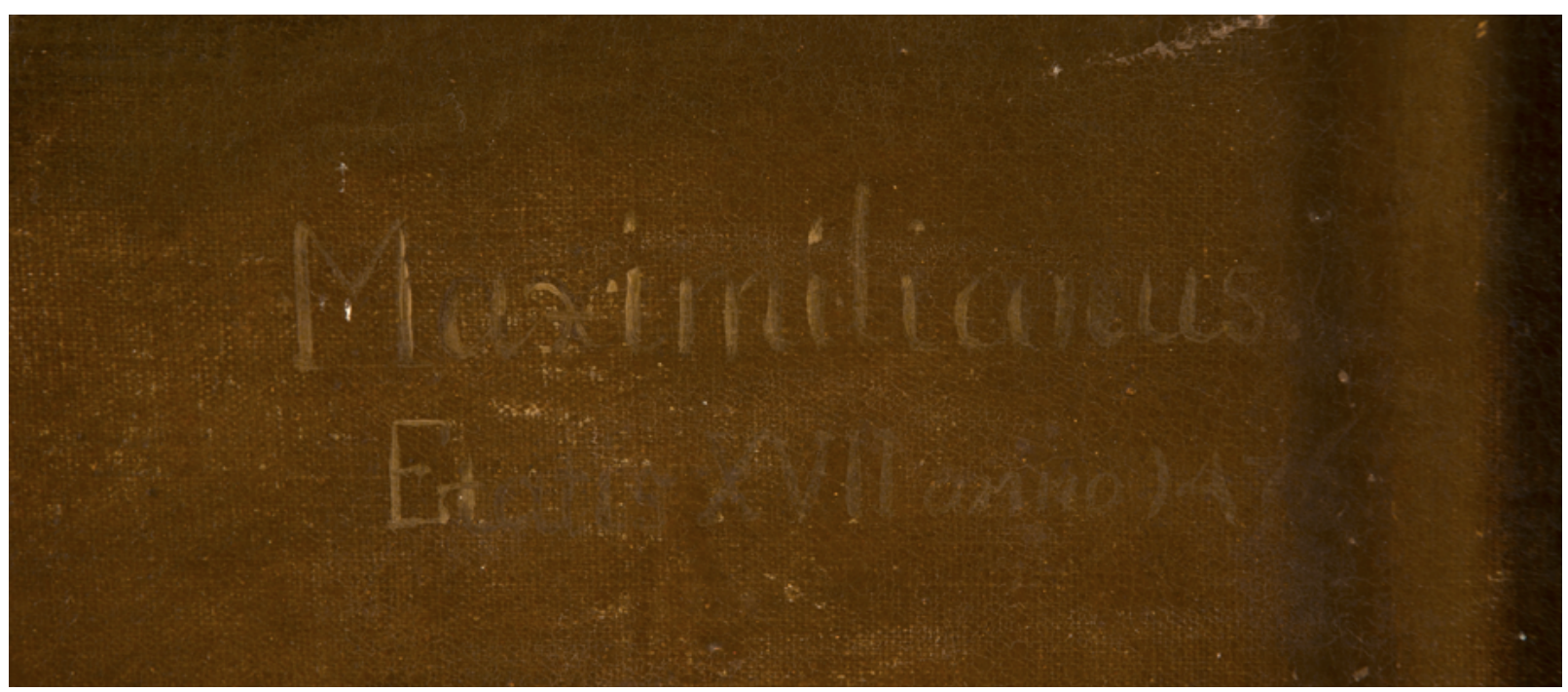

2. Nepoznati slikar, Neuturđeni muškarac (Maksimilijan I. Habsburški), Trakošćan, Dvor Trakošćan, zatečeno stanje, detalj s najmlađim natpisom iz druge intervencije (arhiva HRZ-a, snimka: J. Škudar, 2016.)

Unknown artist, Unidentified Man (Emperor Maximilian I), Trakošćan, Trakošćan Castle, condition before conservation, detail with the youngest inscription from the second intervention (HRZ Photo Archive, J. Škudar, 2016)

jednostavno profiliranom bazom na visokom postamentu čiji je vijenac također jednostavno profiliran. Gornji dio stupa prekriva tamnozelena draperija. S desne strane slike nalazi se nedefinirani arhitektonski oblik u čijem je gornjem dijelu latinski natpis minuskulom: Maximilianus / Etatis XVII anno 1476 (Maksimilijan / u dobi od 17 godina godine 1476). Slika je bila datirana u 15 . stoljeće na temelju natpisa, no zbog stilskih karakteristika i upitne likovne kvalitete razmatrana je i mogućnost da je riječ o kopiji iz 19. ili 20. stoljeća. Također je i sama tehnika ulja na platnu, prava rijetkost do 16. stoljeća, upućivala na kasniji datum nastanka (sl. 1 i 2).

U gornjem dijelu slike čitavom se njezinom širinom protezala vodoravna pukotina koja je upućivala na mijenjanje formata dodavanjem trake novoga platna visine $16 \mathrm{~cm}$. Konzervatorsko-restauratorska istraživanja potvrdila su promjenu formata $u$ naknadnoj intervenciji kad je slika zajedno s platnenom trakom nalijepljena na novo platno (dublirana). Traka je na sliku sa stražnje strane spojena novim platnom, a s prednje strane lijepljenjem jedne uzdužne niti unutar spoja koji je potom ispunjen kredno-tutkalnim kitom. Na većem dijelu toga produžetka slike naslikana je teška tamnozelena draperija koja se s lijeve strane prema dolje nastavljala i preko izvornog oslika tako da je njome zaklonjen gornji dio stupa. Dodani dio sa zelenom draperijom slikan je jednostavnijim, širim potezima, na mekoj bijeloj osnovi i na platnu gušćega tkanja. Analiza pigmenata dokazala je u zelenoj boji draperije prisutnost barijeve bijele (litopon) koja je u upotrebu ušla tek krajem 19. stoljeća kao zamjena za otrovni olovni karbonat (olovno bijelilo), kao i kromne žute ili zelene, također pigmenata uvedenih u 19. stoljeću. ${ }^{2}$ U zbirci Dvora Trakošćan postoji još niz portreta, uglavnom dječjih, s istom tamnozelenom draperijom u gornjem dijelu. Za pretpostaviti je da je posljednjom intervencijom ova slika bila usklađena s tim portretima. Nažalost, ne postoje arhivski izvori o tome kada je i na koji način slika dospjela u Trakošćan. ${ }^{3}$ Površina slike bila je prekrivena slojem vezane površinske prljavštine, lak je potamnio i izgubio prozirnost, a slikani sloj imao je mnogobrojna oštećenja. Na nekim je mjestima stanjen do sloja osnove, a na mjestima je bio vidljiv platneni nosilac. Vidljivi debeli preslici na nekim su se mjestima u listićima odvajali od podloge ili starijih slojeva boje, a na površini slike bile su mnogobrojne ogrebotine.

Testovi topljivosti laka i preslika na izvornom dijelu slike pokazali su prisutnost preslika na čitavoj slici ispod debelog sloja potamnjeloga laka. Lak i vrlo tvrdokoran film od nataložene vezane površinske prljavštine topili su se uz pomoć emulzije za odstranjivanje slojeva $\mathrm{pH}$ vrijednosti 6,5. Unatoč prethodnoj konsolidaciji, tim se postupkom otapao i sloj preslika u listićima koji nije više bio dobro vezan uz podlogu, a čvrsto se vezao za lak. Slikani sloj iz najmlađe naknadne intervencije (tamnozelena draperija) vrlo se lako otapao uz pomoć mješavine 4 dijela etilnog alkohola i 6 dijelova ligroina. ${ }^{5}$ Za odstranjivanje najstarijeg sloja preslika na izvornom dijelu slike bio je potreban viši stupanj polarnosti. Djelotvornom se pokazala mješavina jednakih dijelova etilnog alkohola i ligroina. ${ }^{6}$ Pritom je na nekima od mjesta na kojima su izvođeni testovi topljivosti, pogotovo na crvenom haljetku i inkarnatu šaka, postao vidljiv stariji slikani sloj više likovne kvalitete, čvršći od preslika i dobro vezan za osnovu, ali i stanjen i s vidljivim čvorićima platna. Na području lica otkriveno je više slojeva inkarnata, kao i rekonstrukcija sloja osnove između nosa i gornje usne, izvedena svijetlim kredno-tutkalnim kitom. 


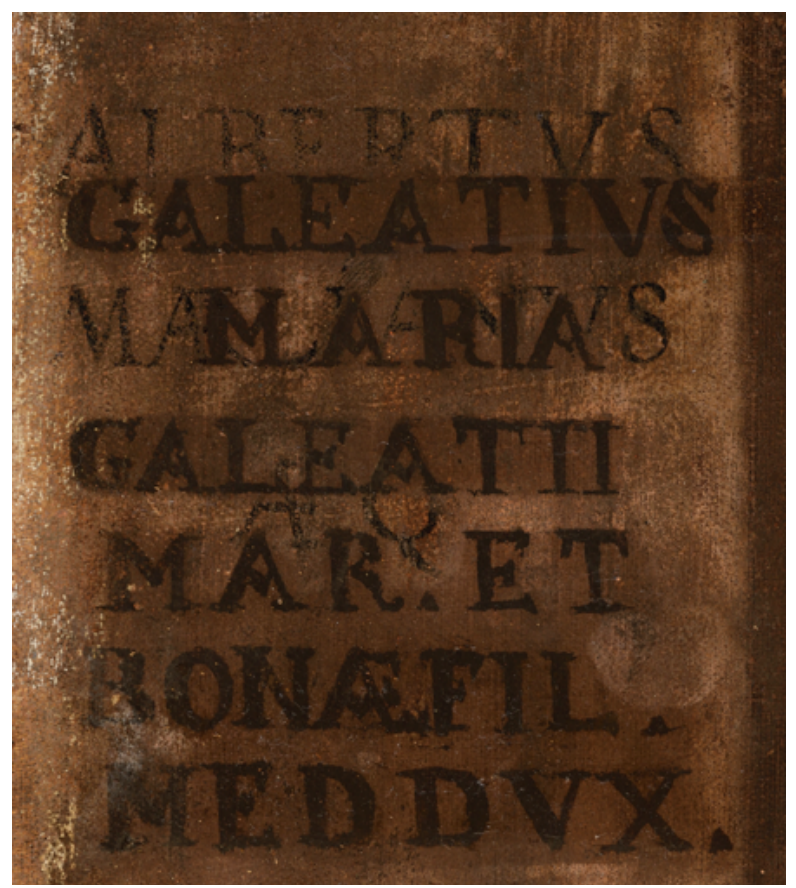

3. Slika tijekom raslojavanja, detalj s natpisom iz prve intervencije (arhiva HRZ-a, snimka: J. Škudar, 2018.)

Painting during layering, detail with inscription from the first intervention (HRZ Photo Archive, J. Škudar, 2018)

Ta je rekonstrukcija rađena na mjestu oštećenja slikanog sloja i osnove, ali je dijelom prekrivala i stariji slikani sloj. Na postamentu stupa pojavili su se i tragovi natpisa.

\section{Portret Galeazza Marije Sforze}

U okviru konzervatorsko-restauratorskih istraživanja proširene su zone odstranjivanja laka i preslika. Parcijalnim odstranjivanjem preslika postao je vidljiv latinski natpis kapitalom na stupu: GALEATIVS / MARIA / GALEATII / MAR. ET / BONAEFIL. / MEDDVX. Puni tekst glasio bi: GALEATIUS / MARIA / GALEATII / MARIAE ET / BONAE FILIBERTI / MEDIOLANI DUX, sa značenjem: Galeazzo Maria (sin) Galeazza Marije i Bone Filiberti / milanski vojvoda. Prema tom je natpisu, inkarnat koji smo zatekli ispod preslika s portretom cara Maksimilijana I., pripadao portretu Galeazza II. Marije Sforze, zvanom Gian Galeazzo.

Daljnim odstranjivanjem preslika ispod upravo otkrivenog natpisa počeo sa nazirati drugi, još stariji natpis koji je počinjao riječju ALBERTUS (sl. 3 i 4). Također su i s desne strane portreta $u$ profilu postale vidljive konture starijeg portreta u poluprofilu, a na samome smo licu naišli i na stariji, treći tip inkarnata, toplijeg tonaliteta od Gian Galleazovog. Snimka infracrvene reflektografije dokazala je prisutnost trećeg, najstarijeg portreta $u$ poluprofilu, za razliku od punog profila, u oba sloja preslika na licu i kosi. Ova su otkrića prezentirana nadležnom konzervatoru, ravnatelju Muzeja dvorca Trakošćan, kustosu zbirke i stručnoj komisiji Hrvatskog restauratorskog zavoda.

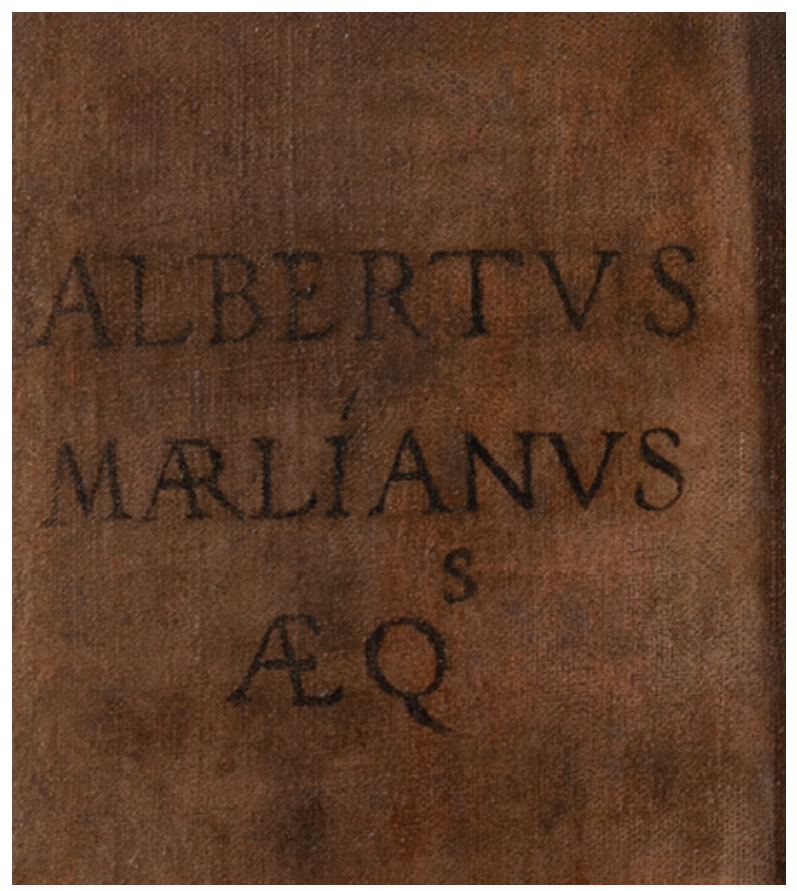

4. Slika nakon radova, detalj s izvornim natpisom (arhiva HRZ-a, snimka: N. Oštarijaš, 2021.)

Painting after conservation, detail with original inscription (HRZ Photo Archive, N. Oštarijaš, 2021)

Komisijski je ustanovljeno da je pri ovakvom stanju slojeva iz naknadnih intervencija moguće sačuvati sloj prve intervencije (portret Gian Galeazza), koja je bila parcijalna i oblikovno dosta nezgrapna, ali da najviše smisla ima odstraniti sve naknadne intervencije i prezentirati prvotnu kompoziciju. ${ }^{7}$ Infracrvena reflektografija i rendgensko snimanje pokazali su da su, unatoč drastičnoj stanjenosti izvornog slikanog sloja, sačuvani gotovo svi likovni elementi prvotnog portreta, odnosno svi elementi koji bi omogućili rekonstrukciju oštećenih dijelova. Stoga se nakon dodatnih konzervatorsko-restauratorskih istraživanja, započelo s raslojavanjem, odnosno postupnim odstranjivanjem slojeva preslika, uz njihovo dokumentiranje i valorizaciju.

Budući da je svako odstranjivanje ireverzibilno, odluka o raslojavanju i odstranjivanju triju preslika ili „doslika“ nije bila ni laka ni jednostavna. Osim već u detaljima vidljive superiorne likovne kvalitete prvotnog portreta, opravdavala ju je i sačuvanost velikog dijela izvorne slike, koju je dokazala snimka infracrvene reflektografije, a potom i rendgenska snimka. Na donošenje je odluke utjecala i specifičnost procesa preslikavanja. Naime, $u$ prvoj, najstarijoj intervenciji, preslikani su natpis na stupu, glava, pozadina i donji dio kose, čime je izvorni portret $u$ poluprofilu pretvoren $u$ portret druge osobe $u$ profilu.

U idućoj intervenciji, slika u zatečenom stanju upotrijebljena je kao podslik za novi, treći portret. Zbog oštećenja slikanog sloja, cijela je preslikana, ali uz ponavljanje većine sadržaja. Drugim riječima, gotovo ista slika 
ponovno je naslikana drugom rukom (sl. 5, 6 i 7). Veća oštećenja slikanog sloja na nekoliko su mjesta na licu i pozadini zapunjena tvrdim žućkastim kitom, promijenjena je opet glava te je portret Gian Galeazza $u$ profilu pretvoren $u$ portret cara Maksimilijana I., također u profilu. Nadalje, preslikan je natpis na stupu, a mladiću je u desnu ruku stavljen svitak, dobio je lanac s križem oko vrata i dršku mača u pasu, uz manžetu lijeve ruke, a na kraju je dodan i natpis.

U trećoj su intervenciji, obilato i neprecizno, mekim bijelim kitom ispunjena nova oštećenja u slikanom sloju. Na licu i rubovima ove su rekonstrukcije prelazile i na slikani sloj. Nadalje, proširen je gornji rub slike, koji je prije toga rezan, kako bi se mogao izvesti ravan spoj s novim platnom. Zatim je slika, zajedno s dodatkom, nalijepljena na novo platno, naslikana je draperija, a na zapunjenim je mjestima oštećenja napravljena gruba rekonstrukcija slikanog sloja uljanim bojama.

\section{Laboratorijske analize i konzervatorsko-restauratorski radovi}

Na 11 je mjesta napravljeno neinvazivno određivanje pigmenata metodom rendgenske fluorescentne spektroskopije, koje je potvrdilo ovu najmlađu intervenciju, $\mathrm{u}$ kojoj je, osim preslika, slici bio promijenjen format dodavanjem komada platna visine $16 \mathrm{~cm}^{8}$ Naime, na čitavoj su slici utvrđeni pigmenti koji su se koristili od srednjeg vijeka naovamo (olovna bijela, željezni oksid - umbra, cinober, bakreni pigment, kalcijev karbonat, olovno kositreno žuta), a samo su u gornjem dijelu slike, na dodanoj traci i draperiji iz najrecentnije intervencije, nađeni i pigmenti koji su u upotrebu ušli u 19. stoljeću, i to barijeva bijela i kromna zelena ili žuta. ${ }^{9}$ U donjem je dijelu slike izdvojen samo jedan uzorak za izradu mikropresjeka. Na mikropresjeku je napravljena energijsko disperzivna spektroskopija i stratigrafska analiza pigmenata. Ni tu nisu nađeni mlađi pigmenti. ${ }^{10}$ Analiza pigmenata na izvornom dijelu slike nije nam previše pomogla $u$ utvrđivanju njezine starosti jer su se isti prirodni pigmenti, koji su na njoj identificirani, upotrebljavali stoljećima. Indikativna je upotreba cinobera na haljetku i inkarnatu s obzirom na to da je cinober bio obilato korišten $u$ doba renesanse. Zbog upotrebe litopona i kromne zelene ili žute, mogli smo biti sigurni da najmlađa intervencija dodavanja platnene trake i njezina oslikavanja draperijom nije starija od 19. stoljeća. Zbog upotrebe kromnih pigmenata, možemo je preciznije smjestiti u prvu polovicu 19. stoljeća. ${ }^{11}$

Stratigrafska analiza pigmenata otkrila je da je tanka osnova, tonirana u svijetlonarančastu boju, rađena na bazi krede te da je na njoj još tanji sloj imprimature od olovnog bjelila, također toniran pigmentima. ${ }^{12}$ Takvu su tehniku dvoslojne osnove u 15 . stoljeću razvili flamanski majstori za slike na drvenom nosiocu. Kako zbog

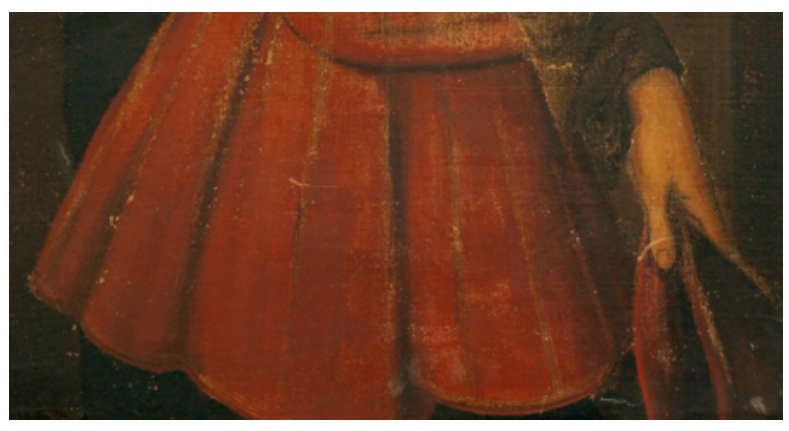

5. Detalj zatečenog stanja (arhiva HRZ-a, snimka: J. Škudar, 2016.) Detail before conservation (HRZ Photo Archive, J. Škudar, 2016)

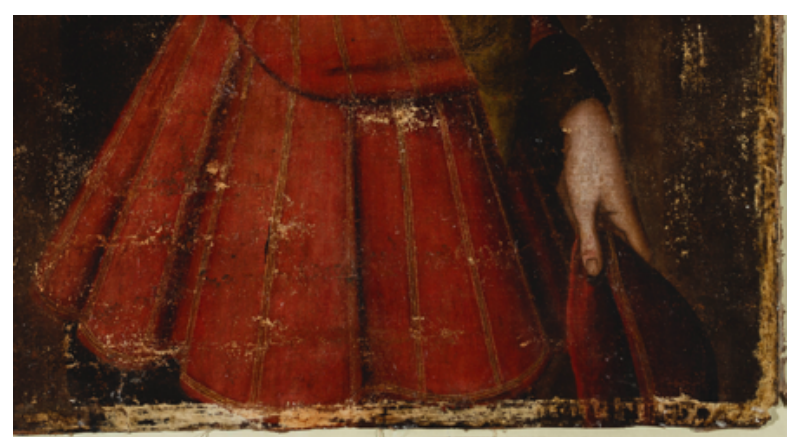

6. Detalj nakon odstranjivanja preslika (arhiva HRZ-a, snimka: G. Tomljenović, 2018.)

Detail after removal of overpainting (HRZ Photo Archive, G. Tomljenović, 2018)

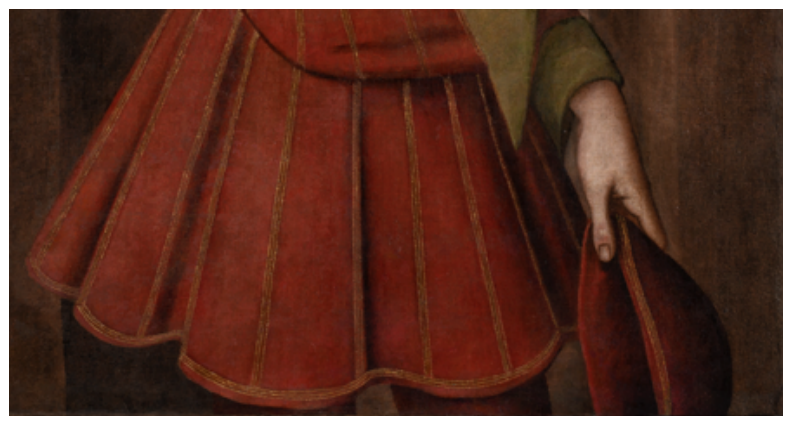

7. Detalj nakon radova (arhiva HRZ-a, snimka: N. Oštarijaš, 2021.) Detail after conservation (HRZ Photo Archive, N. Oštarijaš, 2021)

trgovačkih veza, tako i zbog putovanja sjevernjačkih slikara u Italiju i talijanskih slikara na sjever, sjevernjačko je portretno slikarstvo izvršilo velik utjecaj na lombardsko. Bogati milanski naručitelji divili su se djelima Jana van Eycka, Huga van der Goesa, Rogiera van der Weydena i Hansa Memlinga i čak naručivali portrete u njihovim radionicama. Rogier van der Weyden bio je glavni slikar na burgundskom dvoru Filipa Dobrog. Godine 1458. njegovu je radionicu posjetio Alessandro Sforza i naručio više slika, pa tako i Triptih Sforza koji se čuva u Briselu u Musées des Beaux-Arts. Pune je dvije godine (1461. - 1463.), na nauku u radionici Rogiera van der Weydena, proveo Zanetto Bugatto (oko 1440. - 1475.), 


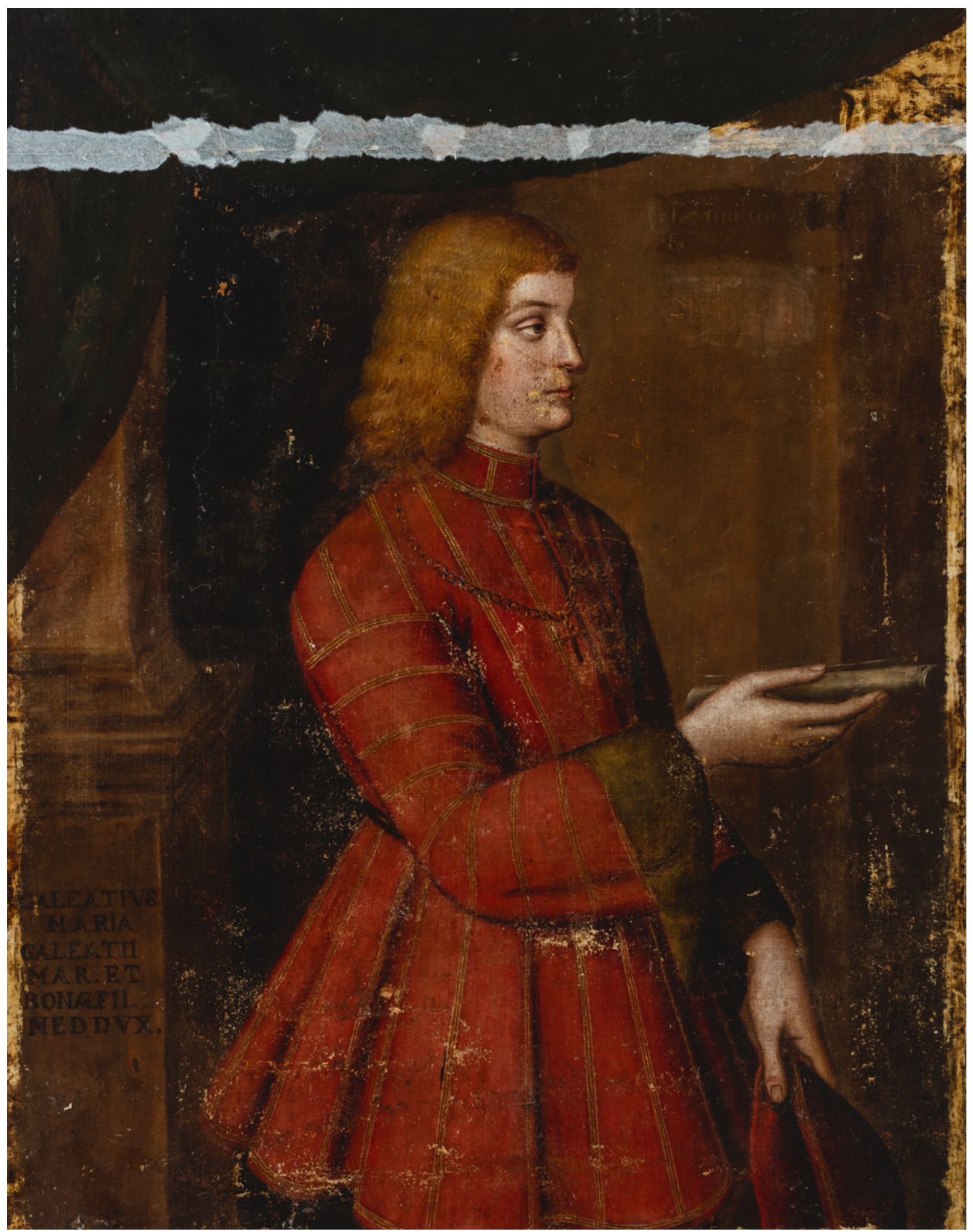

8. Slika tijekom raslojavanja (arhiva HRZ-a, snimka: G. Tomljenović, 2018.)

Painting during layering (HRZ Photo Archive, G. Tomljenović, 2018)

omiljeni dvorski portretist Galeazza Marije Sforze i Bone Savojske. Osim pozitivnog utjecaja na kvalitetu njegovog slikarstva, značajno je bilo i učenje majstorove tehnologije koju je Bugatto proširio na lokalni krug više naraštaja slikara. ${ }^{13}$
Komadić lanenog platnenog nosioca, koji je visio poput viška s ruba u donjem lijevom uglu slike i nije na sebi imao ni osnovu ni slikani sloj, dali smo u Institut Ruđer Bošković na utvrđivanje starosti metodom ${ }^{14} \mathrm{C}$ karbonske analize. ${ }^{14}$ Rezultati analize pokazali su da je platno ili iz 


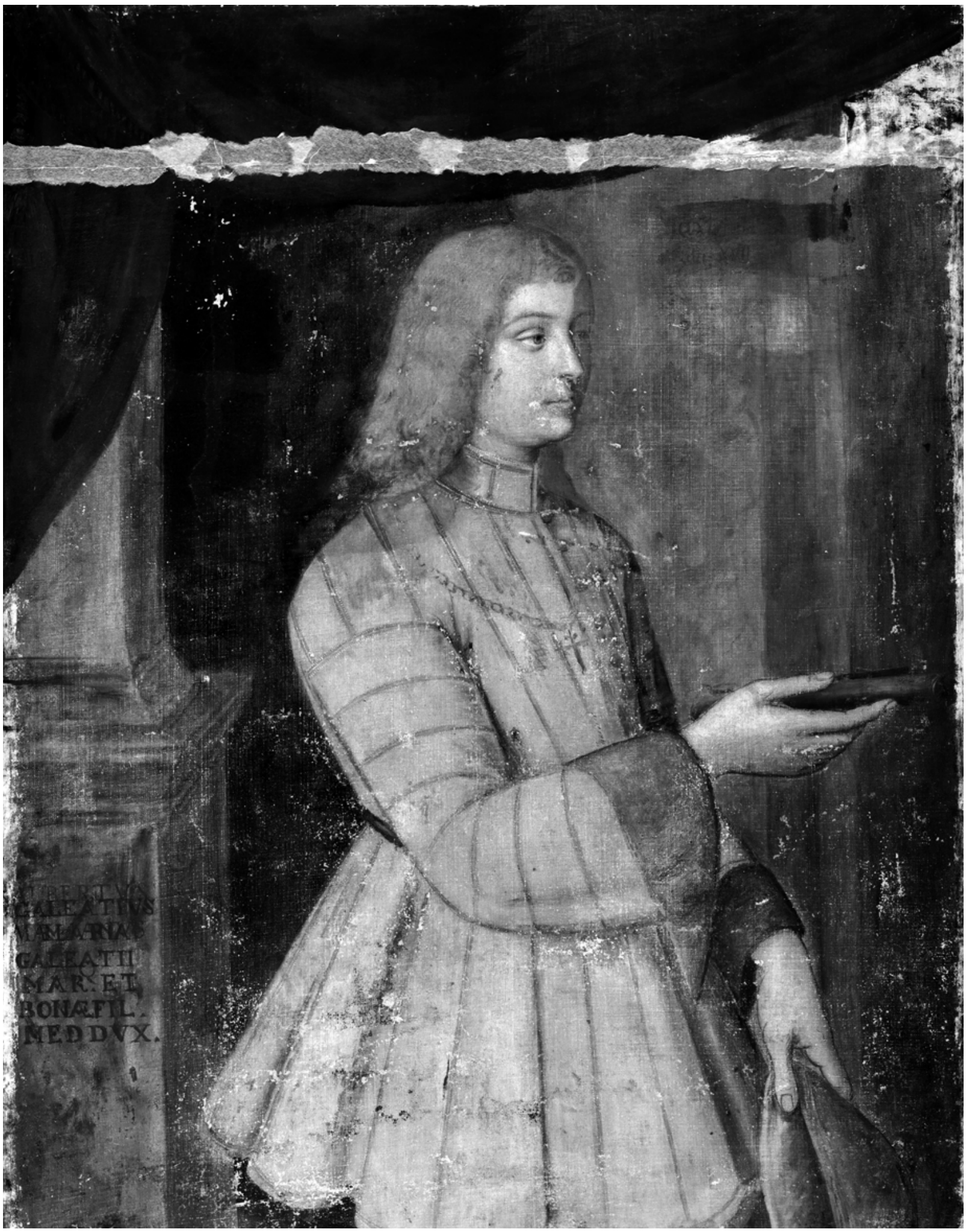

9. Infracrvena reflektografija, snimka tijekom raslojavanja (arhiva HRZ-a, snimka: G. Tomljenović, 2018.) IR-reflectography, image during layering (HRZ Photo Archive, G. Tomljenović, 2018)

16. ili iz 17. stoljeća. Ovaj je dvoznačni rezultat dobiven zbog vrlo nepravilnog oblika kalibracijske krivulje. Intervalom koji pokriva 95,4\% ukupne vjerojatnosti, dobivena su dva, gotovo jednako vjerojatna intervala: 1520. - 1593., s vjerojatnošću od 50,1 \% i 1619. - 1665. s vjerojatnošću od 45,3\%. Platno je dosta gruboga tkanja, gustoće 15 (potka) x 13 (osnova) niti po $\mathrm{cm}^{2}$. Prema mikroskopskoj analizi uzorka i poprečnog presjeka niti platna, najvjerojatnije se radi o lanu. ${ }^{15}$ Po lijevom i desnom okomitom rubu ima sačuvane dijelove živoga ruba, što znači da 


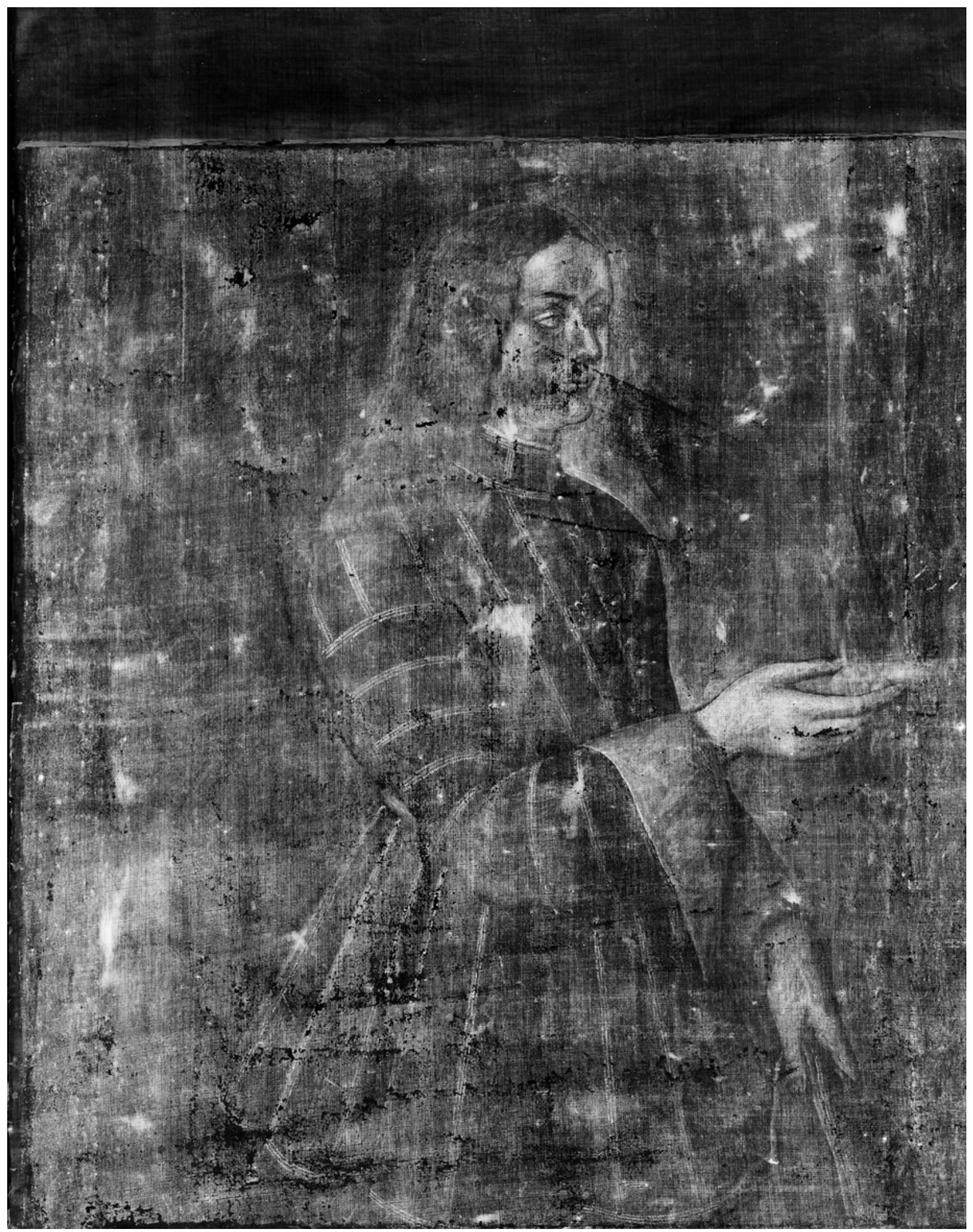

10. Rendgenska snimka tijekom raslojavanja (arhiva HRZ-a, snimka: G. Tomljenović, 2018.)

X-ray during layering (HRZ Photo Archive, G. Tomljenović, 2018)

je tkano na malom tkalačkom stanu koji je opsluživao jedan čovjek. To je tipično za Englesku i sjevernu Italiju početkom 16. stoljeća, prije tehnološkog napretka koji je omogućavao veću širinu platna. ${ }^{16}$ Odstranjivanje laka i preslika čitavo je vrijeme praćeno i kontrolirano pod ultravioletnim svjetlom, a infracrvena je reflektografija rađena $u$ dvije različite faze radova (sl. 8, - 12). Zbog stanja platnenog nosioca, slika je na toplinskom niskotlačnom stolu podložena novim platnom. S idejom da se na sliku i u sliku unese što manje materijala, kao ljepilo smo 


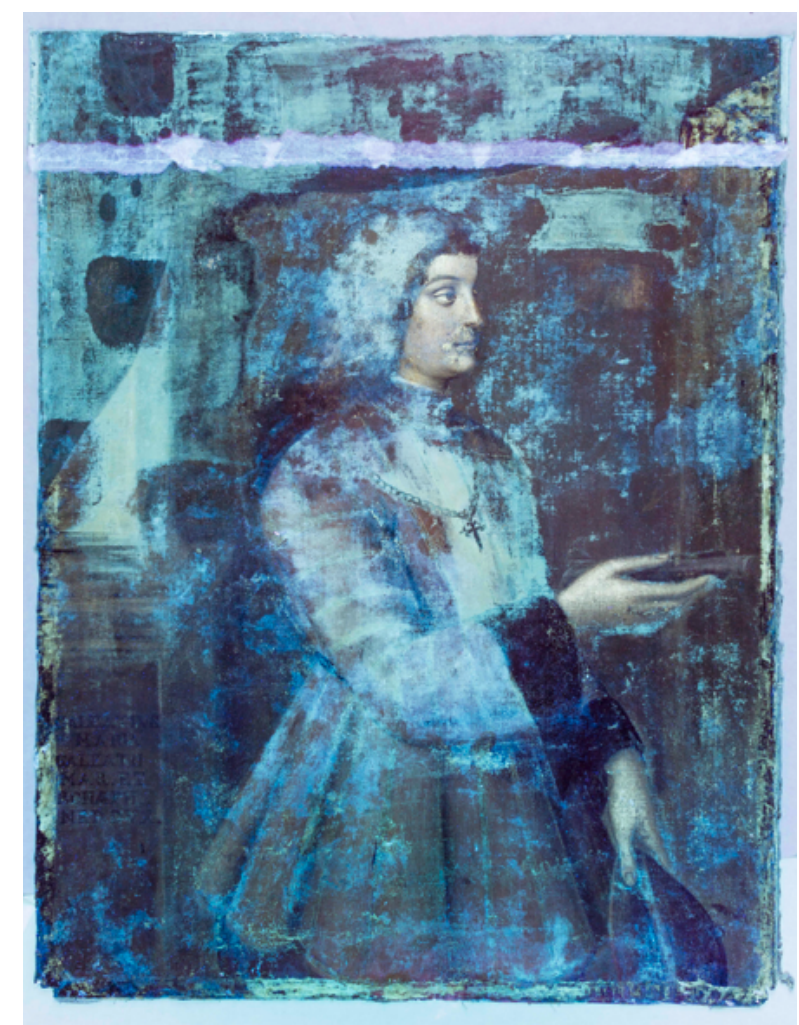

11. Snimka ultravioletne fluorescencije tijekom raslojavanja (arhiva HRZ-a, snimka: G. Tomljenović, 2018.)

UV-fluorescence image during layering (HRZ Photo Archive, G. Tomljenović, 2018)

koristili akrilnu disperziju Plextol D 498 u stanju suhoga filma. Ljepilo je u tekućem stanju naneseno isključivo na novo platno, a zatim osušeno te reaktivirano toplinom $u$ procesu lijepljenja. ${ }^{17}$ Za izolaciju izvornog oslika i kao završna zaštita korišten je trajno reverzibilni urea-aldehidni lak Laropal A81 u koncentraciji od 19\%, nanošen prskanjem iz daljine od oko $50 \mathrm{~cm} .{ }^{18}$ Retuš je rađen prozračno, pointilistički i polutransparentno, isključivo na mjestima oštećenja na kojima je nedostajao slikani sloj. Korišteni su Winsor \& Newton akvarel i urea-aldehidne Gamblin Conservation Colors. ${ }^{19}$

\section{Portret Alberta Marlianija}

Nakon odstranjivanja naknadnih intervencija, pogledu je postao dostupan izvorni portret mladića duge zlatne kose $u$ poluprofilu, u crvenom haljetku sa zlatnom dugmadi, prošivenom zlatnim nitima koje tvore bordure te poprečne (na rukavima) i okomite linearne ornamente. Iznad ovratnika proviruje delikatna čipka bijele košulje. ${ }^{20}$ Promijenjena je i gesta desnom rukom, koja više ne drži svitak, već izgleda kao da mladić nekome pruža ruku (sl. 13a 15). To se uklapa u modu renesansnih ženidbenih portreta koji se $u$ to doba slikaju odvojeno i često šalju zaručnicima prije vjenčanja. Muškarac je s lijeve strane, gleda udesno i impostiran je tako da se očekuje pandan, ženski portret s desne strane, pogleda usmjerenog u suprotnom smjeru,

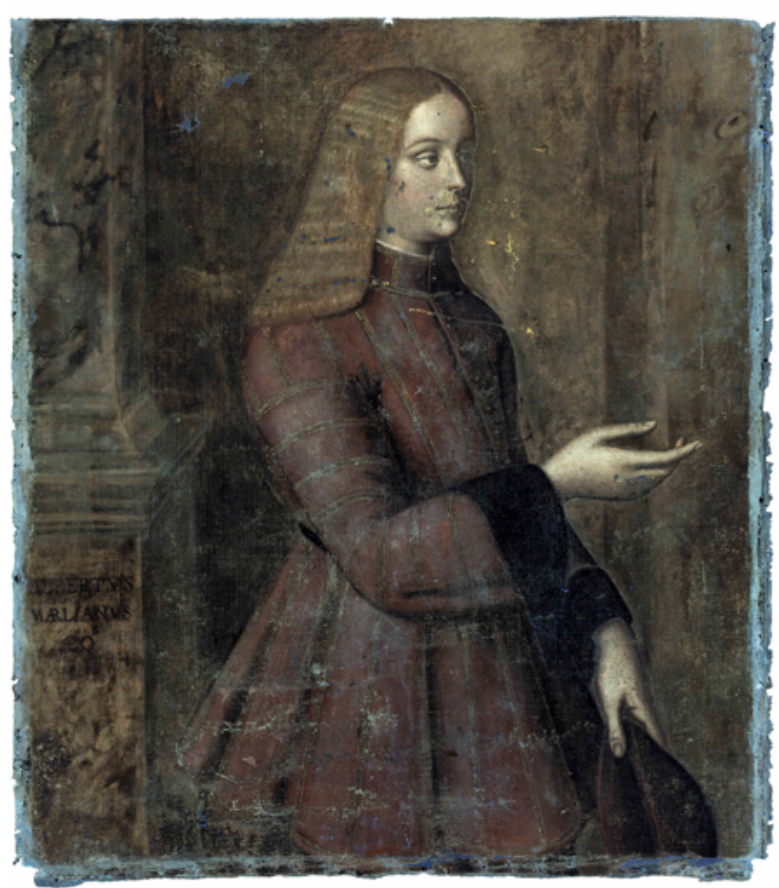

12. Snimka ultravioletne fluorescencije nakon raslojavanja (arhiva HRZ-a, snimka: J. Škudar, 2018.)

UV-fluorescence image after layering (HRZ Photo Archive, J.

Škudar, 2018)

ulijevo $^{21}$. Na stupu je natpis (koji je bio višekratno preslikan), pisan također renesansnom kapitalom: ALBERTUS / MARLÍANUS / $Æ Q^{\mathrm{S}}$ ili u prijevodu: Alberto/Marliani / plemić (od latinski aeques ili eques = konjanik, vitez, plemić). Moguće je i da je $a e q^{\mathrm{s}} \mathrm{u}$ isto vrijeme i skraćenica od aequus, što znači jednak, smiren, pravedan, nepristran $\mathrm{i}$ upućuje i na profesiju i položaj muškarca.

Alberto Marliani, na kojega smo naišli u digitaliziranim lombardskim arhivima i kronikama, bio je pripadnik stare i moćne milanske plemićke obitelji čiji su članovi još za vrijeme vladavine obitelji Visconti, a potom i obitelji Sforza, obnašali visoke dužnosti sudaca, savjetnika, ambasadora, liječnika i znanstvenika pri milanskom dvoru. Obitelj je osobito ojačala u doba dinastije Sforza, ali je izumrla u 18. stoljeću. U milanskim se kronikama Alberto Marliani spominje kao prijatelj Francesca Sforze i jedan od tzv. kapetana i branitelja (capitani e defensori) koji su mu pomogli osvojiti okolicu Milana, a na kraju i sam Milano (26. veljače 1450. godine). Iz stoljeća u stoljeće razni autori navode i da je Francesco Sforza na početku svog boravka u Milanu odsjeo kod svog uzdanika i prijatelja Alberta Marlianija te da je nakon osvajanja grada, umoran došao pred njegovu kuću i ne silazeći s konja, pojeo skroman obrok koji se sastojao od prosenog kruha i vina. ${ }^{22} \mathrm{U}$ obiteljskom stablu obitelji Cicogna Mozzoni, u koju se u 18. stoljeću udala kći jednog od posljednjih 


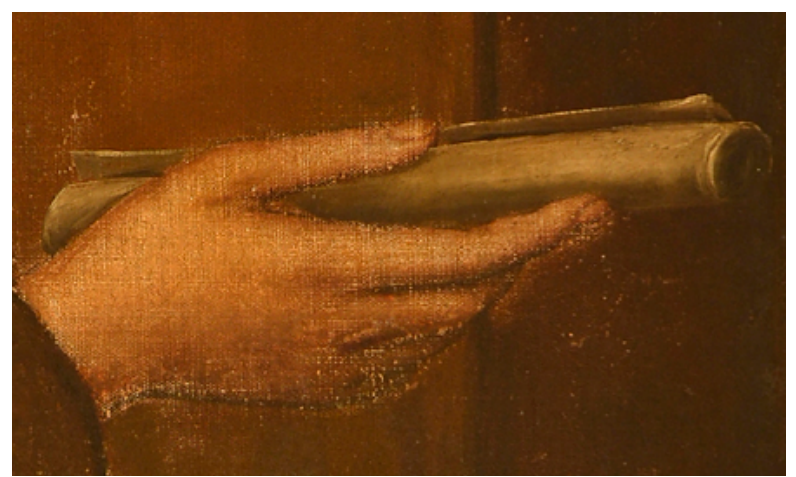

13. Detalj s desnom šakom, zatečeno stanje, (arhiva HRZ-a, snimka: J. Škudar, 2016.)

Detail with right hand, condition before conservation (HRZ Photo Archive, J. Škudar, 2016)

muških predstavnika milanske obitelji Marliani, nalazi se još jedan Alberto Marliani, praunuk starijeg Alberta, po liniji njegovog sina Melchiona. ${ }^{23}$ Melchion je imao sina Luigija, a ovaj sinove Melchiorrea i Alberta. Neki se Alberto Marliani spominje i kao Capitano della Martesana (magistrat općine Martesana sa sjedištem u Vimercateu u Lombardiji), izabran 1485. godine, a kasnije je temeljem sačuvane službene prepiske Francesca Sforze identificiran i kao gradonačelnik Cremone. U povijesti milanskog plemstva spominju se braća Melchiorre i Alberto Marliani kao capitani e defensori. Za Melchiorrea smo u spomenutom obiteljskom stablu našli podatak da je umro 1525. godine.

Uvidjevši o koliko se razgranatoj obitelji radi i u kojoj se mjeri ciklički izmjenjuje određeni broj imena njenih muških pripadnika, vrlo smo brzo izgubili nadu da ćemo sa sigurnošću moći odrediti o kojem se Albertu radi. Sva ova otkrića otvorila su mnoga pitanja. Bilo bi zanimljivo saznati kako je slika postala dio trakošćanske zbirke; je li, kao i glavnina zbirke, došla iz dvorca obitelji Drašković u Klenovniku; radi li se o poklonu ili kupovini; je li kralj Maksimilijan (car Maksimilijan II.), koji je Draškovićima dao Trakošćan u posjed, dao sliku preurediti u portret cara Maksimilijana I. te im je poklonio ili čak prodao. Plemićke su obitelji isticale svoje davno podrijetlo galerijama predaka i rodoslovljima. Obiteljska galerija Draškovića nastajala je od druge polovice 16. stoljeća do početka 18 . stoljeća. Oko prve četvrtine 18. stoljeća stvorena je i njihova galerija ovalnih portreta i portreta vladara, časnika i crkvenih velikodostojnika koja je naglašavala njihove političke veze i važnost. ${ }^{24}$ Najvjerojatnije je portret cara Maksimilijana I. pribavljen $u$ to doba, a možda je sliku u 19. stoljeću kupila Julijana Drašković prilikom jednog od svojih putovanja $\mathrm{u}$ Italiju.

Obitelji Marliani i Sforza čvrsta su poveznica s Milanom i lombardskim portretnim slikarstvom. No, zašto je netko u 16. stoljeću dao možda izraditi portret čovjeka koji je živio u 15. stoljeću (stariji Alberto Marliani) i zašto je taj portret pretvoren u portret drugog čovjeka 15. stoljeća,

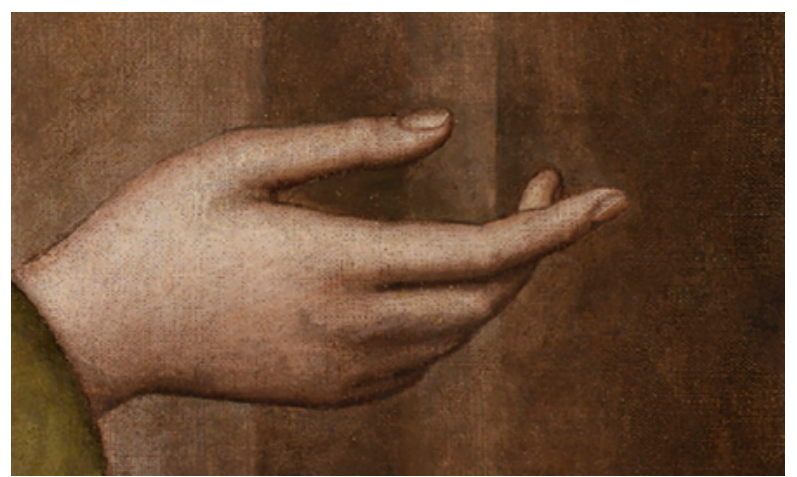

14. Detalj s desnom šakom, podslik nakon odstranjivanja preslika (arhiva HRZ-a, snimka: J. Škudar, 2019.)

Detail with right hand, underpainting after removal of overpainting (HRZ Photo Archive, J. Škudar, 2019)

pripadnika iduće generacije (Gian Galeazzo Maria Sforza), a zatim i u cara Maksimilijana I.? Odgovor možda leži u burnim političkim previranjima u Milanskom Vojvodstvu početkom 16. stoljeća.

Galeazzo II. Maria Sforza (1469. - 1494.) bio je sin Galeazza Marije Sforze i Bone Savojske (Filiberti) te unuk začetnika dinastije Sforza, Francesca Sforze. Postao je milanski vojvoda 1476. godine nakon ubojstva svoga oca, u dobi od 7 godina. Majka mu je bila regent do 1481 . godine, a zatim je regent postao njegov stric Ludovico Maria Sforza, zvan Il Moro. Krajem 1488. godine oženio se s Izabelom Napuljskom (Aragonskom), a početkom 1489. godine priredili su raskošnu svadbenu svečanost $u$ Milanu. Scenografiju za tu svečanost radio je Leonardo da Vinci kojeg je, kao vojnog inženjera, kipara, slikara i scenografa velikih dvorskih svečanosti, angažirao Ludovico Moro. ${ }^{25}$ Gian Galeazzo umro je 1494. pod nerazjašnjenim okolnostima, u dobi od 25 godina, i vlast nad Milanskim vojvodstvom preuzeo je njegov stric, Ludovico Moro. Zanimljivo je da je iste godine Ludovico Moro uspio ugovoriti brak između Gian Galeazzove sestre (Bianca Maria Sforza) i Maksimilijana I. kako bi si osigurao carevu zaštitu od francuskih aspiracija na Milansko Vojvodstvo. ${ }^{26}$

Udajom za cara Maksimilijana I., Bianca Maria Sforza preselila se na Maksimilijanov dvor u Innsbrucku koji je postao drugi centar milanskog plemstva i umjetnika. Prije 2. francuske invazije 1499. godine, njezin je stric Ludovico Moro poslao svoje sinove Ettorea Massimiliana i Francesca II. u Innsbruck pod njezinu zaštitu. Kako su odrastali, oko Morovih se sinova okupljalo lombardsko plemstvo, pristalice povratka na vlast dinastije Sforza. Među njima je i kardinal Luigi Marliani, alkemičar, humanist, liječnik i savjetnik cara Maksimilijana I. i njegovog unuka Karla V. te Karlovog sina Filipa Lijepog. ${ }^{27}$ Ettore Massimiliano uspio je vladati Milanskim vojvodstvom od 1512. do 1515. godine, između dviju francuskih okupacija, a Francesco II. bio je posljednji milanski vojvoda iz obitelji Sforza, od 1521. do 1535. godine, nakon što mu je to omogućio Karlo V. ponovno osvojivši Milano. 


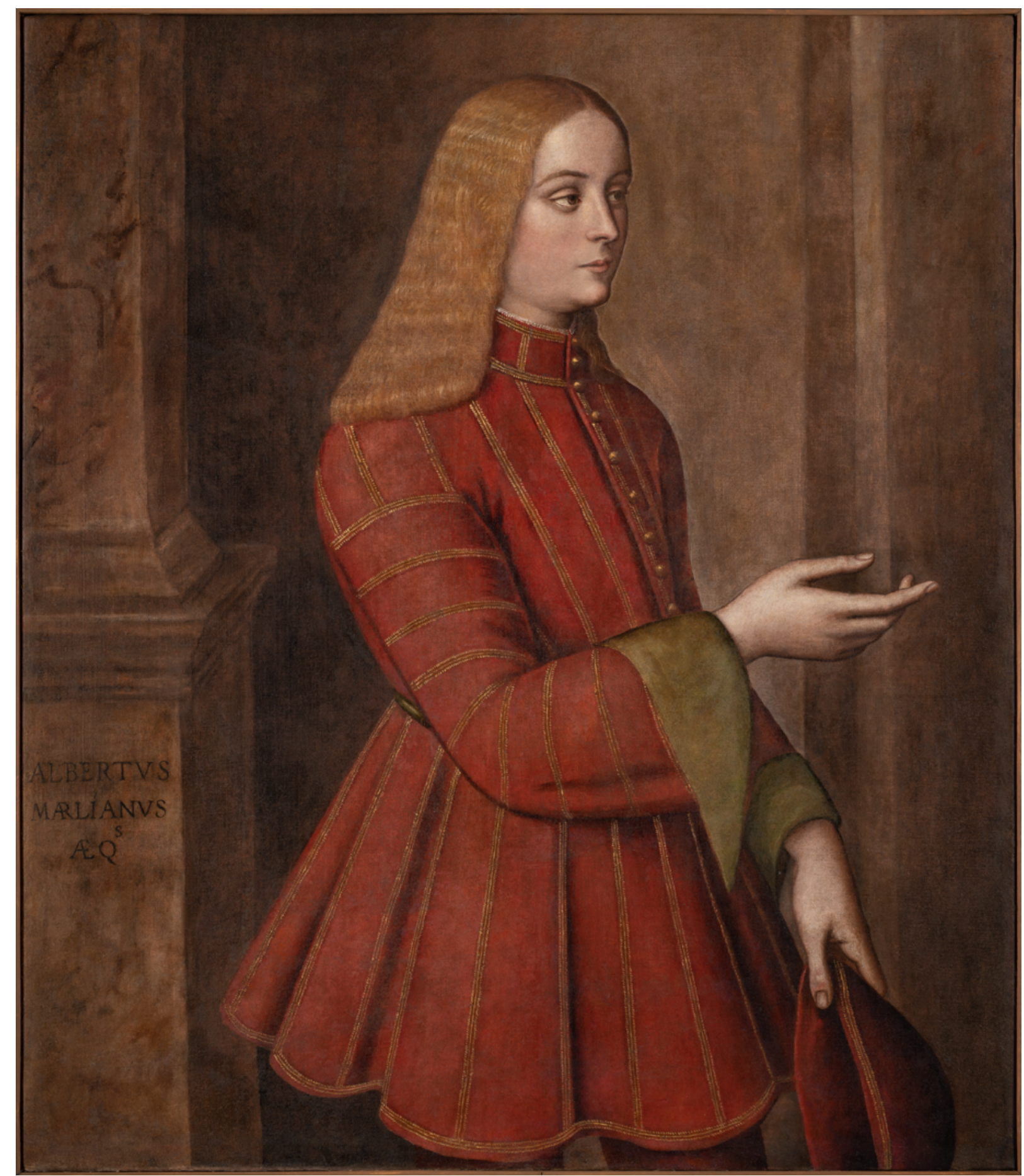

15. Slika nakon radova (arhiva HRZ-a, snimka: N. Oštarijaš, 2021.)

Painting after conservation (HRZ Photo Archive, N. Oštarijaš, 2021)

Luigija Marlianija, oko 1520. - 1521. godine, vidimo kao mogućeg naručitelja idealiziranog i moguće imaginarnog portreta svoga pretka koji je njihovu obitelj čvrsto i neraskidivo vezao uz obitelj Sforza te su postali i dijelom njihove legende. ${ }^{28}$ Moguće je također i da je portret rađen prema starijem izvorniku. Naime, Marliani su bili veliki patroni umjetnosti i bila je glasovita njihova velika zbirka umjetnina, kao i njihova biblioteka u palači Marliani u Milanu koja je krajem 18. stoljeća promijenila vlasnike te je potpuno preuređena. U njihovu je palaču radi knjiga zalazio i sam Leonardo. ${ }^{29}$ Luigija Marliania je Karlo V. postavio za biskupa od Tuya u Galiciji, a umro je od kuge, 1521. godine u Briselu. Vjerojatno nakon smrti kardinala Marlianija, portret je zbog sličnosti (zlatna kosa i mladenačka dob), za vrijeme Francesca II., mogao biti pretvoren u Gian Galeazza, u ime veličanja povijesti obitelji Sforza. U Maksimilijana I., djeda kojeg je obožavao, mogao ga je dati preurediti i Karlo V. Zbog spleta opisanih događaja i 
relacija u relativno kratkom periodu, rezultata karbonske analize i svijetle i tonirane osnove te zbog onovremene muške mode u sjevernoj Italiji, ovaj bismo portret Alberta Marlianija vremenski smjestili u prvu četvrt 16. stoljeća.

Zahvaljujući mješovitim stilskim obilježjima, u kojima su istovremeno prisutne i asocijacije na sredinu 15. stoljeća i neke manirističke značajke, vrlo je moguće da je portret rađen prema starijem predlošku na drvenom ili zidnom nosiocu. U Milanu, pa čak i Innsbrucku, u doba manirizma / visoke renesanse, u prvoj je četvrti 16. stoljeća bio aktivan veliki broj takozvanih leonardeskija, slikara na koje je Leonardo tijekom svog dugog boravka u Milanu izvršio golem utjecaj. ${ }^{30}$ Njegovi su učenici i sljedbenici kopirali njegova djela i pokušavali ga imitirati. Neki kritičari čak tvrde da je veličinom svog autoriteta na dosta vremena uspio zatrti svaku mogućnost razvoja originalnih individualnih stilova $u$ Lombardiji. Iz Leonardove radionice s kraja njegovog prvog milanskog perioda potječu njegovi direktni učenici, kao što su Giovanni Antonio Boltraffio (oko 1467. - 1516.), Marco d'Oggiono (spominje se od 1487.; umire 1524.), Gian Giacomo Caprotti da Oreno, poznatiji kao Salaino ili Salai (1480. - 1524.), Francesco Melzi (oko 1491. - oko 1570.) i Giovanni Pietro Rizzoli, zvan Giampetrino (aktivan 1495. - 1549.). Jedino je Giampetrino s vremenom uspio razviti rafinirani autonomni stil, vjerojatno potaknut manje ortodoksnim leonardeskijima, kao što su bili Andrea Solario (oko 1465. - 1514.), Bernardino Luini (1480. - 1532.), Cesare da Sesto (1477. 1523.) i Gaudenzio Ferrari (1475. - 1546.), te je taj posredni Leonardov utjecaj prvi počeo širiti preko Alpa i Pirineja. ${ }^{31}$

\section{Zaključak}

Iako je zbog stanja slikanog sloja na portretu Alberta Marlianija teško iščitati sve likovne karakteristike, profinjeno difuzno svjetlo i određena ukočenost te slična stilizacija

\section{Bilješke}

1. U Inventarnoj knjizi muzejskih predmeta Dvora Trakošćan, u kategoriji Zbirka slika, slika je unesena pod inventarnom oznakom 182 i datirana u 15. stoljeće, vjerojatno temeljem natpisa u njezinu gornjem dijelu.

2. Litopon, u: Hrvatska enciklopedija (Leksikografski zavod Miroslav Krleža), 6, 604. Zagreb, 2004, https://www.enciklopedija.hr/natuknica.aspx?id=36828 (12. 5. 2018); EASTAUGH et al., 2004, 38.

3. Dr. sc. Marini Bregovac Pisk zahvaljujemo na informaciji kako tijekom rada na svojoj doktorskoj disertaciji u arhivima nije naišla na podatke o akviziciji ove slike.

4. WOLBERS, 2000, 100. 2 g Pemulen Tr-2 polimernog emulgatora prema receptu Richarda Wolbersa koji je modificirao Paolo Cremonesi, otopljeno je u mješavini $12 \mathrm{ml}$ benzilnog alkohola i $200 \mathrm{ml}$ destilirane vode $u$ kojoj je prethodno rastopljen $1 \mathrm{ml}$ trietanolamina. idealizirane ljepote $u$ koju se kod većine lombardskih leonardeskija pretvorila dostojanstvenost Leonardovih likova, upućuju na majstorov posredni utjecaj. Veze s leonardesknim krugom mogu se primijetiti i u nekim tehnološkim aspektima, kao što su upotreba imprimature od olovnog bjelila (Boltraffio npr.), toniranje osnove (Leonardo i drugi) i prisutnost organskog crnog pigmenta u svim slojevima boje koja slici daje diskretno sivkast sedefasti ton (Marco d'Oggiono). ${ }^{32}$ Autor bi mogao biti pripadnik suzdržane i konzervativne struje lombardskog portretnog slikarstva, obilježenog manirističkim elementima koje je preuzeo (a uočavamo ih npr. kroz nedostatak interesa za perspektivu i realistične proporcije), kao i navedenim elementima leonardesknog stila.

Stigavši kao portret Maksimilijana I. Habsburškog zahvaljujući važnoj poziciji grofova Drašković u Habsburškoj Monarhiji, nakon što je neko vrijeme i na nekom drugom mjestu bio portret Gian Galeazza, $u$ Bednji je ostao otkriveni portret Alberta Marlianija, jednog od legendarnih osvajača Milana koji su Francescu Sforzi pomogli da se domogne vlasti koju je Sforza uspješno prenio i na svoje potomke. Jedan je od njih doveo na svoj dvor Leonarda da Vincija i time izmijenio tijek razvoja lombardskog slikarstva. Majstor je u svojoj radionici izvršio golem utjecaj na krug svojih suradnika, a oni su ga koncentrično širili na nove sljedbenike Leonardova stila, pa tako i na autora ovog portreta. Fascinantan je put ove slike do čuvaonice Dvora Trakošćan, ali i njezino gotovo slučajno oslobađanje iz kukuljice naknadnih intervencija i pretvorba u možda najstariji otkriveni portret na području kontinentalne Hrvatske. Ovo je djelo također i vrijedan doprinos poznavanju lombardskog portretnog slikarstva kroz sagledavanje razvoja specifičnih lokalnih obilježja pod utjecajem stila firentinskog majstora, kako izravnim, tako i preko brojnih epigona.

5. CREMONESI, 2004, 102. LE 4 (mješavina $20 \mathrm{ml}$ etilnog alkohola i $30 \mathrm{ml}$ ligroina) prema Wolbers-Cremonesijevom modularnom sistemu čišćenja površina, prezentiranom na radionicama i predavanjima Richarda Wolbersa i Paola Cremonesija održanih 2011. godine u Muzeju suvremene umjetnosti (R. Wolbers) i Hrvatskom restauratorskom zavodu (P. Cremonesi).

6. CREMONESI, 2004, 102. LE 5 prema Wolbers-Cremonesijevom modularnom sistemu čišćenja površina.

7. Odluka je donesena na temelju zaključaka stručne komisije Hrvatskog restauratorskog zavoda, uz suglasnost nadležnog konzervatora, ravnatelja Muzeja dvorca Trakošćan i kustosa zbirke. 8. Provedena su sljedeća istraživanja: rendgenska fluorescentna spektroskopija (XRF), energijsko disperzivna spektroskopija (SEM/EDS), stratigrafska analiza. Vidi: HRZ, Margareta Klofutar, Marijana Fabečić, Domagoj Mudronja, Laboratorijsko izvješće br. 153/2018, Zagreb, 2018. 
9. EASTAUGH et al., 2004, 38, 99. Kromna žuta sintetizirana je početkom 19. stoljeća, a u upotrebu ulazi oko 1814.

10. Mikrofotografija poprečnog presjeka uzorka otkriva četiri sloja; svjetlonarančasto-žuti sloj osnove, svjetlosivo-smeđi sloj imprimature s crtežom i dva slikana sloja, oba žuta. HRZ, Margareta Klofutar, Domagoj Mudronja, Laboratorijsko izvješće br. 95/2019, Zagreb, 2019.

11. Zbog skupog i kompliciranog procesa proizvodnje kromnih pigmenata, već je u 2. polovici 19. stoljeća prevladala upotreba kadmijeve žute. EASTAUGH et al., 2004, 96.

12. Tehnika nanošenja dva sloja osnove razvijana je u 15. i 16. stoljeću. Tanki i upojni kredno-tutkalni sloj osnove na sebe je dobro vezao tanji neupijajući sloj finije mljevenog punila $u$ uljnom vezivu, tzv. imprimaturu. Kombinacija punila i ulja površini daje dublji, sivkast sjaj. Pored utjecaja na reflektirajuća svojstva površine, uvođenje imprimature olakšalo je postupak nanošenja boje. U 15. i 16. stoljeću koristila su se dva tipa materijala za sloj osnove: kalcijev sulfat (gips) i kalcijev karbonat (kreda). Usto, svijetle osnove pripadaju ranijem tipu osnova - razdoblju koje odgovara ranoj i zreloj renesansi. HENRIQUES ANTUNES et al., 2016, 4791-4795. Referirajući se na strane i domaće radove, Jelena Zagora piše: „....u 16. su stoljeću u Italiji učestale imprimature svijetlog do srednjeg tona, podjednako na slikama na drvu i na platnu. Variraju sastavom i bojom, ponekad i unutar opusa pojedinih slikara: od prigušene ružičaste, svijetlonarančaste i bež do blijedosive, a najčešće su tople smećkasto-sive boje. Najzastupljenije su sjeverno od Apenina i u Veneciji.“ ZAGORA, 2017, 75.

13. MAJOCCHI, 2018, 166-169.

14. Zahvaljujemo dr. sc. Ines Krajcar Bronić, voditeljici laboratorija za mjerenje niskih radioaktivnosti Instituta Ruđer Bošković u Zagrebu, na vremenu i trudu koje je uložila kako bi nam razjasnila rezultate 14C karbonske analize. Vidi više u arhivi HRZ-a: Andreja Sironić, Ines Krajcar Bronić, Ispitni izvještaj 017-2363/1/2018, Institut Ruđer Bošković, Zagreb, 2018; Andreja Sironić, Ines Krajcar Bronić, Prilog Ispitnom izvještaju br. 017-2363/2/2018, Institut Ruđer Bošković, Zagreb, 2018.

15. HRZ, Margareta Klofutar, Domagoj Mudronja, Laboratorijsko izvješće br. 95/2019, Zagreb, 2019.

16. Canvas, The Grove Encyclopedia of Materials and Techniques in Art, tur: Gerald W.R. Ward, Oxford University Press, 2008, 79-82, The Grove Encyclopedia of Materials and Techniques in Art - Google Knjige (23. 7. 2018.).

17. Detaljniji se podaci o konzervatorsko-restauatorskim radovima na slici nalaze u službenoj dokumentaciji Hrvatskog restauratorskog zavoda. HRZ, Marina Đurović, Jelena Pasarić, Izvješće o provedenim konzervatorsko-restauratorskim radovima na tri slike i jednom ukrasnom okviru iz Dvora Trakošćan, Zagreb, 2019. 18. Sintetički lak Laropal A 81 (urea-aldehidna smola) i nakon starenja je topljiv otapalima niske polarnosti koja neće oštetiti slikani sloj ispod njega. Ovaj lak, za razliku od lakova na bazi prirodnih smola, ne stvara kemijske veze s podlogom (cross-linking), stoga ne izaziva ni stanjivanje slikanog sloja. Radi inhibiranja oksidacijskih procesa, koji uzrokuju ubrzano tamnjenje površine, laku je dodan i stabilizator Tinuvin-292 u koncentraciji $2 \%$, kako bi se spriječila potreba za skorim ponovnim odstranjivanjem laka. 19. Gamblin Conservation Colors odlikuju se čistoćom pigmenata, njihovim odličnim svojstvima, od visoke pokrivnosti do transparentnosti, a također i trajnom reverzibilnošću jer se kao njihovo vezivo koristi Laropal A 81.

20. Ovako je ukrašena, $k$ tome još i crvena odjeća, bila znak pripadnosti visokom staležu vladara, prinčeva i plemića. Visoki ovratnik haljetka i naglašeni struk upućuju na kasno 15. stoljeće, no nešto širi i ravni rukavi s istaknutim manžetama, dužina do pola bedra i krupni nabori u donjem dijelu u modu su ušli početkom 16. stoljeća. I mekana je kapa s rubom okrenutim prema gore bila vrlo popularna u prvoj polovini 16. stoljeća. Od 1520. na dalje, pod španjolskim utjecajem, u modu sve više ulaze raskošni, veliki čipkasti ovratnici na košuljama, a dužina muške odjeće drastično se skraćuje. https://www.hisour.com/europeanmens-fashion-in-1400-1500-32362/ (17. 1. 2019.).

21. PANOFSKY, 171 Zahvaljujemo dr. sc. Sanji Cvetnić, red. prof. na Odsjeku za povijest umjetnosti Filozofskog fakulteta u Zagrebu, što nas je uputila na studiju E. Panofskog o flamanskom slikarstvu u kojoj objašnjava princip ženidbenih i bračnih portreta $u$ doba renesanse.

22. PIETRO, 1639, 652; CORTE, 1718, 36; MAJOCCHI, 2018, 40.

23. Genealogia Cicogna Mozzoni e famiglie correlate. https:// gw.geneanet.org/fcicogna?lang=en\&pz=costanza+nicolina\&nz= visconti\&p=luigi\& $n=$ marliani\&oc $=5$ (7. 5. 2018.).

24. BREGOVAC PISK, 2012, 392.

25. Leonardo je između 1482. i 1499. boravio na milanskom dvoru kao vojni inženjer, kipar, slikar i scenograf velikih dvorskih svečanosti u službi Ludovica Sforze; nakon što je Ludovica Sforzu Maksimilijan I. Habsburški svrgnuo sa prijestolja te nakon što je francuski kralj Louis XII svrgnuo Maksimilijana I., ponovno je boravio u Milanu 1506. - 1513. MAZZOTA, 2014, 17, 41-42; GEDDO, 2014, 71.

26. ADY, 1907, 115-140.

27. Rosenthal spominje kako više autora navodi da je kardinal Luigi Marliani autor poznatog mota PLUS ULTRA cara Karla V. ROSENTHAL, 1973, 200.

28. Afinitet učenih patrona prema idealiziranoj androginoj ljepoti bio je tipičan za milanski dvor krajem 15. i početkom 16. stoljeća. SPRING et al., 2011, 101.

29. Azzolini opisuje kako je Leonarda s ovom moćnom obitelji povezao doktor Fazio Marliani. U Leonardovim je bilješkama vidljivo da su mu poznate knjige koje su Marliani napisali ili posjedovali. AZZOLINI, 2006, 172.

30. Zahvaljujemo dr. Cristini Geddo, ekspertici za Leonardove učenike i sljedbenike u Milanu te lombardske majstore i umjetničke kolekcije 17. i 18. stojeća, što je s nama podijelila svoje radove, kao i radove drugih znanstvenika, o mnogobrojnim Leonardovim sljedbenicima u Milanu i Lombardiji.

31. GEDDO, 2014, 71-72.

32. SPRING et al., $2011,82,90$. 


\section{Izvori}

HRZ Hrvatski restauratorski zavod

\section{Literatura}

CECILIA MARY ADY, A History of Milan under the Sforza, London, 1907.

MONICA AZZOLINI, Leonardo's Anatomical Studies in Milan, u: Visualizing Medieval Medicine and Natural History, 1200-1550., ur: Jean Ann Givens, Karen Reeds, Alain Touwaide, 2006., 147-176 MARINA BREGOVAC PISK, Obitelj Drašković kao naručitelji i kupci umjetnina (na primjeru dvorca Trakošćan), doktorski rad, Filozofski fakultet Sveučilišta u Zagrebu, Zagreb, 2012.

BARTOLOMEO CORTE, Notizie istoriche intorno a medici Scrittori milanesi, e a principali ritrovamenti fatti in Medicina dag''Italiani etc., Milano, 1718.

PAOLO CREMONESI, L'uso dei solventi organici nella pulitura di opere policrome, II Prato, 2004.

NICHOLAS EASTAUGH, VALENTINE WALSH, TRACEY CHAPLIN, RUTH SIDDALL, Pigment Compendium: A Dictionary and Optical Microscopy of Historic Pigments, Oxford, 2004.

CRISTINA GEDDO, Giampetrino - "Leonardeschi tra Lombardia ed Europa: i 'Giampietrino' della Mitteleuropa”, u: Lombardia ed Europa. Incroci di storia e cultura, ur: D. Zardin, Milano, 2014., 69-108

VANESSA HENRIQUES ANTUNES, ANTONIO CANDEIAS, MARIA L CARVALHO, JOÃO COROADO, VITOR SERRÃO, MARIO CACHÃO, A multidisciplinary approach to the study of the brightening effects of white chalk ground layers in 15th and 16th century paintings, Analytical Methods, 8 (2016.), 4785-4797

\section{Summary}

Jelena Pasarić, Marina Đurović

\section{ALBERTO MARLIANI IN THE HEART OF BEDNJA}

Conservation of the painting Unidentified Man (perhaps Emperor Maximilian I) from the large collection of portraits at the Trakošćan Castle and Museum has been carried out at the Croatian Conservation Institute, because the painted layer was flaking. The oil-on-canvas painting $(119 \times 87.5 \mathrm{~cm})$ is the work of an unidentified artist. On the basis of the Latin inscription Maximilianus / Etatis XVII anno 1476 (Maximilian / at the age of 17 in 1476) in the upper part of the painting, museum documentation dates it to the $15^{\text {th }}$ century. Conservation and natural-science research identified three subsequent interventions. As part of the non-invasive research, ultraviolet fluorescence, infrared reflectography, X-ray and X-ray reflectography imaging were carried out at 11 different locations on the painting. Invasive research was kept to a minimum. Solubility tests on the layer of surface dirt, varnish and overpainting, and microscopic analysis of the cloth thread were performed, and only one sample was taken for mi-
FABIO AUGUSTO MAJOCCHI, Francesco I Sforza: Milano nel cuore dell'Europa, Milano, 2018., https://www.academia.edu/40105492/ Francesco_I_Sforza_Milano_nel_cuore_dell_Europa._I_rapporti_ tra_Milano_e_la_Borgogna (21. 5. 2019.)

ANTONIO MAZZOTTA, Leonardeschi: Leonardo e gli artisti lombardi, Florence, 2014.

ERWIN PANOFSKY, Early Netherlandish Painting: Its Origins and Character, New York, San Francisco, London, 1971. [1951.] GIOVANNI PIETRO, De Crescenzi Romani. Corona Della Nobiltà D'Italia, O Vero Compendio Dell'Istorie Delle Famiglie Illustri, Milano, 1639.

EARL E. ROSENTHAL, The Invention of the Columnar Device of Emperor Charles V at the Court of Burgundy in Flanders in 1516, Journal of the Warburg and Courtauld Institutes, 36 (1973.), 198-230 MARIKA SPRING, ANTONIO MAZZOTTA, ASHOK ROY, RACHEL BILLINGE, DAVID PEGGIE, Painting Practice in Milan in the 1490s: The Influence of Leonardo, Leonardo da Vinci: Pupil, Painter and Master. National Gallery Technical Bulletin, 32 (2011.), 78-112 RICHARD WOLBERS, Cleaning Painted Surfaces: Aqueous Methods, London, 2000.

JELENA ZAGORA, Povijesni razvoj obojenih podloga u talijanskom slikarstvu od 15. do sredine 18. stoljeća - dosadašnje spoznaje i otvorena pitanja, Portal, 8 (2017.), 73-94

crosection to perform stratigraphic analysis and energydispersive spectroscopy. The minimum required amount of canvas was taken for the C-14 dating.

The identification of painted layers led to the realization that the original portrait of Alberto Marliani, member of an extremely important and powerful Milanese noble family, was turned into a portrait of Galeazzo II Maria Sforza during the first intervention. On that occasion, the head and pedestal of the pillar with the Latin inscription ALBERTUS / MARLÍANUS / $Æ Q^{S}$ (Alberto Marliani nobleman) were painted over. The three-quarter view of Alberto Marliani was transformed into Gian Galeazzo's almost full profile, and a new Latin inscription GALEATIVS / MARIA / GALEATII / MAR ET / BONAEFIL. / MEDDVX. (Galeazzo Maria (son of) Galeazzo Maria and Bono Filiberti / Duke of Milan) was added to the pillar pedestal. Interestingly, during the next intervention, this partially altered portrait was actually used as underpainting for the portrait 
of Emperor Maximilian I. The painting was completely covered with a new painted layer; but, apart from the altered face and the addition of a chain with a cross around the neck, the hilt of a sword at the waist and a scroll in the hand, all the elements were simply repeated in the new layer.

Due to the presence of barium white (lithopone) and chrome yellow or green in the painted layer, it was concluded that the last intervention occurred in the $19^{\text {th }}$ century. At the time, it was also lengthened by $16 \mathrm{~cm}$ through the addition of new canvas in the upper part of the painting. Dark green drapery was painted on the added canvas and part of the older painted layer.

During conservation, all subsequent interventions were removed from the painting. Further historical, archival, historical and art research has contributed to a better understanding of the stylistic features of the work within the specific local and historical context.

KEYwoRDs: Trakošćan, Leonardeschi, Mannerism, Sforza, Marliani, stratification, Emperor Maximilian I 
